\title{
Biodiesel Synthesis from Pongamia pinnata oil over Modified $\mathrm{CeO}_{2}$ Catalysts
}

\author{
Venkatesh, ${ }^{1,2}$ Sathgatta Zaheeruddin Mohamed Shamshuddin, ${ }^{* 1,2}$ Manjunatha Shyamsundar, ${ }^{1,2}$ Vanagoor \\ Thammannigowda Vasanth ${ }^{1}$ \\ ${ }^{1}$ Chemistry Research Laboratory, HMS Institute of Technology, NH4, Kyathsandra, Tumkur, Karnataka, India. \\ 2 Research and Development Center, Bharathiar University, Coimbatore, India. \\ *mohamed.shamshuddin@gmail.com.
}

Received March 24 ${ }^{\text {th }}, 2014 ;$ Accepted May 19 ${ }^{\text {th }}, 2014$

\begin{abstract}
This study investigates the use of $\mathrm{CeO}_{2}, \mathrm{ZrO}_{2}, \mathrm{MgO}$ and $\mathrm{CeO}_{2}-\mathrm{ZrO}_{2}, \mathrm{CeO}_{2}-\mathrm{MgO}, \mathrm{CeO}_{2}-\mathrm{ZrO}_{2}-\mathrm{MgO}$ mixed oxides as solid base catalysts for the transesterification of Pongamia pinnata oil with methanol to produce biodiesel. $\mathrm{SO}_{4}{ }^{2-} / \mathrm{CeO}_{2}$ and $\mathrm{SO}_{4}{ }^{2-} / \mathrm{CeO}_{2}-\mathrm{ZrO}_{2}$ were also prepared and used as solid acid catalysts for esterification of Pongamia pinnata oil (P-oil) to reduce the \% of free fatty acid (FFA) in P-oil. These oxide catalysts were prepared by an incipient wetness impregnation method and characterized by techniques such as $\mathrm{NH}_{3}$ TPD for surface acidity, $\mathrm{CO}_{2}$-TPD for surface basicity and powder $\mathrm{X}$-ray diffraction for crystalinity. The effect of nature of the catalyst, methanol to P-oil molar ratio and reaction time in esterification as well as in transesterification was investigated. The catalytic materials were reactivated \& reused for five reaction cycles and the results showed that the ceria based catalysts have reasonably good reusability both in esterification and transesterification reaction. The test results also revealed that the $\mathrm{CeO}_{2}-\mathrm{ZrO}_{2}$ modified with $\mathrm{MgO}$ could have potential for use in the large scale biodiesel production.
\end{abstract}

Keywords: Biodiesel, Transesterification, Pongamia pinnata oil, modified $\mathrm{CeO}_{2}, \mathrm{CeO}_{2}-\mathrm{ZrO}_{2}, \mathrm{MgO}$.

\section{Introduction}

The rapid depletion of fossil fuel reservoirs has made biodiesel as an alternative fuel in recent years due to its similar characteristics to diesel fossil fuel. Moreover, biodiesel is ecofriendly since it produces exhaust gas free from sulphur \& aromatic compounds and it is biodegradable \& non-toxic [1-4].

Biodiesel is produced by the transesterification of triglycerides of oils and fats with low molecular mass alcohols, like methanol in presence of catalysts. The conventional catalysts for the transesterification reaction are homogeneous strong bases (e.g. alkali hydroxides and methoxides) or homogeneous strong acids (e.g. $\mathrm{H}_{2} \mathrm{SO}_{4}, \mathrm{HCl}, \mathrm{H}_{3} \mathrm{PO}_{4}$ ) [5]. Commonly, bases are preferred over acid catalysts due to their fast reaction rates and less corrosive properties. But the removal of the base after the reaction is difficult, because of the formation of soap and emulsion which makes separation of ester difficult [6]. Efforts have been made in recent years towards to the development of heterogeneous catalysts to produce biodiesel in which separation or purification of the reaction products is much easier [7].

Cerium dioxide $\left(\mathrm{CeO}_{2}\right)$ is a multifunctional inorganic compound holding a great promise for a wide range of technological applications, including heterogeneous catalysis. $\mathrm{CeO}_{2}$ is widely
Resumen. En este trabajo se investiga el uso de los óxidos mixtos $\mathrm{CeO}_{2}, \mathrm{ZrO}_{2}, \mathrm{MgO}$ and $\mathrm{CeO}_{2}-\mathrm{ZrO}_{2}, \mathrm{CeO}_{2}-\mathrm{MgO}, \mathrm{CeO}_{2}-\mathrm{ZrO}_{2}-\mathrm{MgO}$ como catalizadores básicos sólidos en la transesterificación con metanol de aceite de Pongamia pinnata (aceite-P) para producir biodiesel. También se prepararon $\mathrm{SO}_{4}{ }^{2-} / \mathrm{CeO}_{2}$ and $\mathrm{SO}_{4}{ }^{2-} / \mathrm{CeO}_{2}-\mathrm{ZrO}_{2}$ y se usaron como catalizadores ácidos para la esterificación del aceite-P y reducir el \% de ácidos grasos libres (FFA). Los óxidos se sintetizaron por un método de impregnación a mojado incipiente y se caracterizaron por técnicas como $\mathrm{NH}_{3}-\mathrm{TPD}$, para medir la acidez superficial, $\mathrm{CO}_{2}-\mathrm{TPD}$ para la basicidad de la superficie y difracción de rayos $\mathrm{X}$ para obtener la cristalinidad. Se investigaron el efecto de la naturaleza del catalizador, la razón molar entre metanol y aceite-P y el tiempo de reacción, tanto para la transesterificación como para la esterificación. Los catalizadores se reactivaron y reusaron por cinco ciclos de reacción y los resultados mostraron que los catalizadores a base de ceria pueden reusarse razonablemente bien para ambas reacciones. Asimismo se mostró que el óxido $\mathrm{CeO}_{2}-\mathrm{ZrO}_{2}$ modificado con $\mathrm{MgO}$ tiene potencial para su uso en producción de biodiesel a gran escala.

Palabras clave: Biodiesel, Transesterificación, aceite de Pongamia pinnata, $\mathrm{CeO}_{2}, \mathrm{CeO}_{2}-\mathrm{ZrO}_{2}$ modificada, $\mathrm{MgO}$.

used in redox catalysis and as an effective antioxidant. Despite the considerable interest on $\mathrm{CeO}_{2}$ catalytic systems, $\mathrm{CeO}_{2}$ has not been studied yet as a solid acid or solid base catalyst [8].

It has reported that the incorporation of $\mathrm{CeO}_{2}$ into $\mathrm{ZrO}_{2}$ increases the acidity, which is evidenced by low $\mathrm{H}_{0} \max$ values. Ceria-zirconia mixed oxides showed enhanced redox as well as acid-base properties [9].

Biodiesel can be synthesized by using vegetable oils such as palm oil, rapeseed oil, jatropha oil, rubber seed oil, etc. Since, Pongamia pinnata trees are grown extensively in southern parts of India (especially in Karnataka State) and abundant availability of the seeds, Pongamia pinnata oil (P-oil) was selected for the present study to synthesize biodiesel. Further, P-oil is less expensive compared to other vegetable oils, which makes the production of biodiesel from P-oil much more economical. Biodiesel has been synthesized from P-oil by using base catalysts such as $\mathrm{KOH}, \mathrm{NaOH}, \mathrm{MgO}-\mathrm{ZrO}_{2}, \mathrm{MgO}$, etc [10-12] and acid catalysts such as sulfuric acid [13]. Further, it has been reported that the biodiesel obtained from P-oil shows no corrosion on piston metal and piston liner when compared to biodiesel obtained for other oil seeds [14].

In this article focus is made on the synthesis and characterization of ceria (C) \& its modified forms such as its solid acid forms like sulfated ceria (SC), ceria-zirconia (CZ), sul- 
fated ceria-zirconia (SCZ), as acid catalysts for esterification to reduce the $\%$ FFA and its solid base forms such as $\mathrm{CeO}_{2}$ $\mathrm{MgO}(\mathrm{CM}), \mathrm{CeO}_{2}-\mathrm{ZrO}_{2}-\mathrm{MgO}(\mathrm{CZM})$, as base catalysts for the transesterification to produce biodiesel from Pongamia pinnata oil (P-oil). Pure metal oxides such as ceria $(\mathrm{C})$, zirconia $(\mathrm{Z})$ and $\mathrm{MgO}(\mathrm{M})$ were also used as either solid acid or solid base catalysts. The effect of nature of the catalyst, methanol: P-oil molar ratio, reaction time in both esterification and transesterification was investigated. Reusability \& reactivation studies of these catalysts was also taken-up.

\section{Results and discussion}

\section{Catalyst characterization}

\section{Total surface acidity (TSA)}

The total surface acidity (TSA) and total surface basicity (TSB) values of solid catalysts used in the present study are given in Table 1.

TSA values of the solid acids used in the present study followed the order:

$$
\mathrm{SCZ}>\mathrm{SC}>\mathrm{CZ}>\mathrm{Z}>\mathrm{C}
$$

Pure ceria and pure zirconia were found to consist of both acidic \& basic sites (Table 1). However, over pure ceria the number of acidic sites were lower than the number of basic sites i.e., TSB of pure $\mathrm{CeO}_{2}$ was higher than TSA. On the other hand TSA of pure $\mathrm{ZrO}_{2}$ was found to be higher than its TSB. Therefore, pure ceria can be considered as more basic and pure zirconia as more acidic catalyst.

It has been reported that the incorporation of ceria into zirconia or vice-versa increases the acidity of the resulting mixed oxide (i.e., $\mathrm{CeO}_{2}-\mathrm{ZrO}_{2}$ ) to a reasonable extent [9]. The incorporation of zirconium cation in to the ceria unit cell or vice versa modifies the surface acid-base sites, as the exposed $\mathrm{Ce}^{4+}$ and $\mathrm{Zr}^{4+}$ ion act as Lewis acid sites. Both $\mathrm{CeO}_{2}$ and $\mathrm{ZrO}_{2}$ exhibit same metal-oxygen stoichiometry but possess different ionic characters. Ceria is considered to be more ionic than zirconia. The acid strength of the mixed oxide varies depending on the charge to radius ratio of the cation as well. The $\mathrm{Zr}^{4+}$

Table 1. TSA and TSB values of solid catalysts.

\begin{tabular}{ccc}
\hline Catalyst & TSA (mmoles/g) & TSB (mmoles/g) \\
\hline Z & 0.39 & 0.12 \\
C & 0.29 & 0.69 \\
CZ & 0.61 & 0.76 \\
SC & 0.78 & - \\
SCZ & 0.96 & - \\
CM & - & 0.87 \\
CZM & - & 1.12 \\
M & - & 0.42 \\
\hline
\end{tabular}

ion has an ionic radius of $0.84 \AA$ which is smaller than that of $\mathrm{Ce}^{4+}(0.97 \AA)$ and is expected to generate strong acid sites in their mixed form.

Further, it is well cited in literature that the sulfation of pure ceria or pure zirconia increases the acidity of these pure oxides to a certain extent [15]. A similar finding has been observed in the present study, i.e., both sulfated ceria and sulfated zirconia were found to be highly acidic than their pure forms. It is also reported that, in case of ceria which is more basic, upon sulfation, acidic sites are generated at the expense of basic sites [16].

In case of $\mathrm{SCZ}$, the impregnation of sulphate ions on $\mathrm{CZ}$ support enhanced the number of acidic sites which may be due to the existence of different types of sulphate phases such as $\mathrm{CeOSO}_{4}$ and $\mathrm{Zr}\left(\mathrm{SO}_{4}\right)_{2}$ as reported in the literature [17].

Total surface basicity (TSB)

TSB values of solid bases used for the present work followed the order:

$$
\mathrm{CZM}>\mathrm{CM}>\mathrm{CZ}>\mathrm{C}>\mathrm{M}>\mathrm{Z}
$$

It is reported that the basicity of pure oxides are in descending order i.e., $\mathrm{CeO}_{2}, \mathrm{MgO}$ and $\mathrm{ZrO}_{2}, \mathrm{CeO}_{2}$ was found to be highly basic when compared to either $\mathrm{MgO}$ or $\mathrm{ZrO}_{2}$ [18]. It is known that ceria as well as magnesia consisted of basic sites. When these oxides are mixed together i.e., ceria-magnesia mixed oxide is formed. The mixed oxide may consist of basic sites associated with both ceria as well as magnesia. Therefore, ceria-magnesia $(\mathrm{CM})$ is more basic than either pure ceria $(\mathrm{C})$ or pure magnesia (M). However, among mixed oxides, CZM was found to be highly basic because when $\mathrm{Mg}$ (II) ions are impregnated in $\mathrm{CZ}$ support the number of basic sites may increase on the surface of the $\mathrm{CZ}$.

\section{PXRD analysis}

PXRD patterns of solid acids (C, Z, CZ, SC, SCZ) are given in Figure 1. Pure ceria shows the characteristic reflection at $2 \theta=28.5,33.4,47.3,56.2$ which corresponds to the fluorite structure of ceria [19]. PXRD pattern of pure zirconia consisted of both monoclinic reflections at $2 \theta=24.5,28.3,31,41.5$ and tetragonal reflections at $2 \theta=30.2,35.1,50.4,60.0$ [20]. In case of $\mathrm{CZ}$ mixed oxides reflections due to both fluorite structure of ceria and reflections due to tetragonal phase of zirconia could be observed. But reflections due to monoclinic phases of zirconia were not observed. This indicates the structure stabilizing property of ceria on zirconia.

As can be seen in the Figure 1, the PXRD pattern of $\mathrm{CZ}$ and SCZ differ very much indicating a strong influence of sulfate ions on ceria-zirconia mixed oxides. In the PXRD pattern of SCZ, in addition to reflections due to fluorite structure of ceria and tetragonal phase of zirconia, reflections due to different types of surface zirconium sulfates such as zirconium sulfate hydroxide $\left[\mathrm{Zr}(\mathrm{OH})_{2} \mathrm{SO}_{4}\right]$ and zircosulfate $\left[\mathrm{Zr}(\mathrm{SO} 4)_{2}\right]$ were observed. No reflections pertaining to cerium sulphate are seen [21]. 


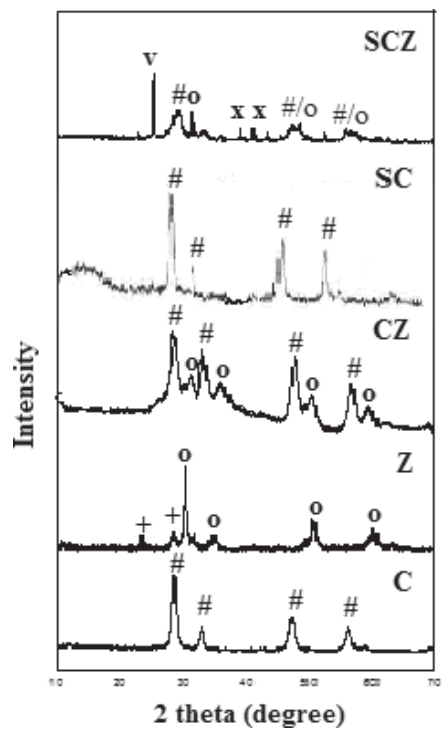

Fig. 1. PXRD pattern solid acids. $[\#=$ ceria; $+=$ monoclinic zirconia, $\mathrm{o}=$ tetragonal zirconia; $\left.\mathrm{v}=\mathrm{Zr}\left(\mathrm{SO}_{4}\right)_{2} ; \times=\mathrm{Zr}(\mathrm{OH})_{2} \mathrm{SO}_{4}\right]$.

Figure 2, illustrates the PXRD patterns of solid bases such as, M, CM, CZM. Pure MgO (M) shows the characteristic reflections at $2 \theta=36,42.8,62.2$ corresponding to its rock salt structure [22]. In case of CM, reflections due to fluorite structure of ceria as well as reflections due to rock salt structure of magnesia could be observed.

Further, in the PXRD pattern of CZM in addition to the reflection pertaining to the rock salt structure of $\mathrm{MgO}$, fluorite structure of ceria, reflections due to tetragonal phase of zirconia are also seen.

\section{Catalytic activity of the catalysts (in BD synthesis)}

Step-1: Reduction of \% of FFA in P-oil via esterification

\section{Effect of nature of solid acid catalyst}

The acid value (\% FFA) of P-oil as a function of TSA of different solid acid catalysts is given in Figure 3. A correlation between the TSA and the catalytic activity of solid acids in esterification was observed. The order of catalytic activity of solid acids was found to be:

$$
\mathrm{SCZ}>\mathrm{SC}>\mathrm{CZ}>\mathrm{Z}>\mathrm{C}
$$

i.e., $\mathrm{SCZ}$ being highly acidic was more active and $\mathrm{CeO}_{2}$ which was least acidic showed lowest activity in esterification reaction.

\section{Step-2: Production of biodiesel from P-oil}

Effect of nature of solid base catalyst

The yield (\%) of biodiesel (BD) as a function of TSB of different solid base catalysts used for the present study is given in Figure 4. Similar to solid acids, a correlation between the TSB and the catalytic activity of solid bases was observed. The

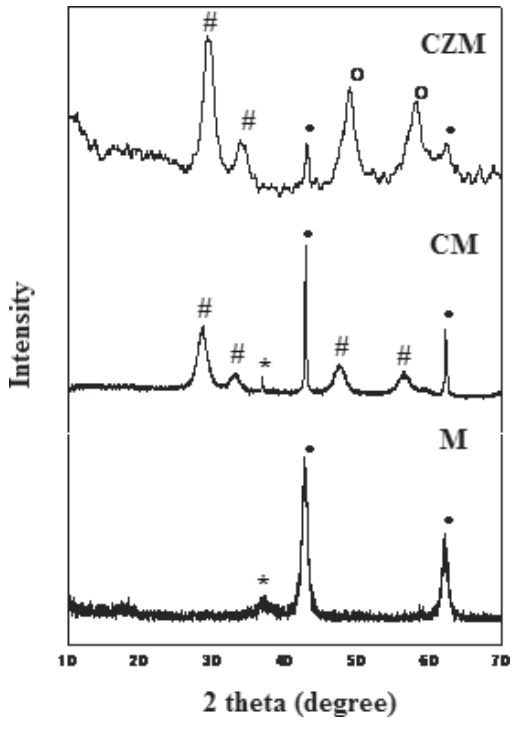

Fig. 2. PXRD patterns of solid bases $[*=$ magnesia; $\#=$ ceria; $o=$ tetragonal zirconia].

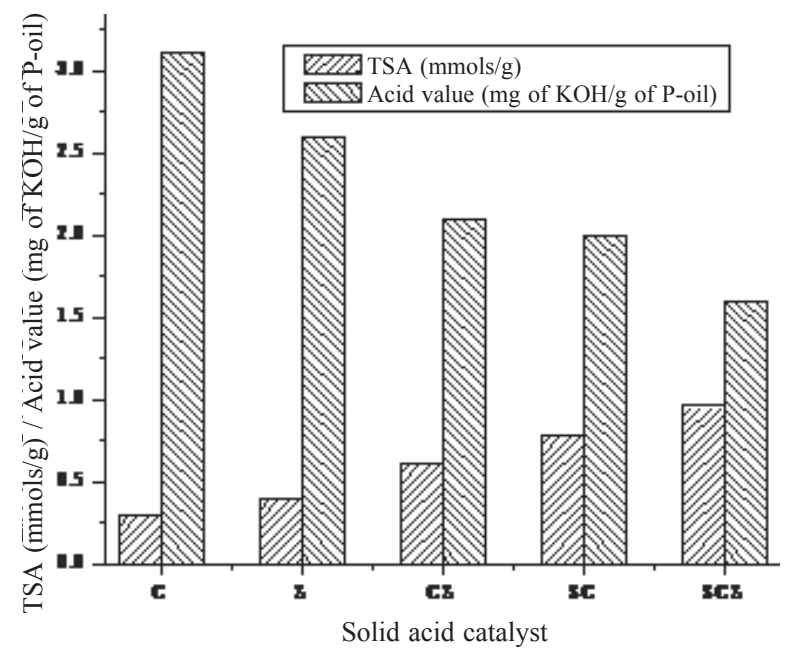

Fig. 3. Acid value of P-oil as a function of TSA of solid acid catalysts.

solid base CZM being most basic was highly active in base catalysed transesterification of P-oil to yield biodiesel. When the catalytic activities of pure oxides such as $\mathrm{CeO}_{2}$ or $\mathrm{ZrO}_{2}$ or $\mathrm{MgO}$ were compared in base catalyzed transesterification, the catalyst activity was found to be in the order:

$$
\mathrm{CeO}_{2}>\mathrm{MgO}>\mathrm{ZrO}_{2}
$$

It has been reported that, pure ceria is more basic than magnesia or zirconia [18]. When pure basic oxides i.e., $\mathrm{CeO}_{2}$ or $\mathrm{MgO}$ were used in transesterification, the color of the reaction mixture changed from yellow to gray. This can be attributed to the presence of 'strong' basic sites present on these oxides. However, such color change was not observed when mixed oxides such as $\mathrm{CZ}$ or CZM were used as catalysts. 


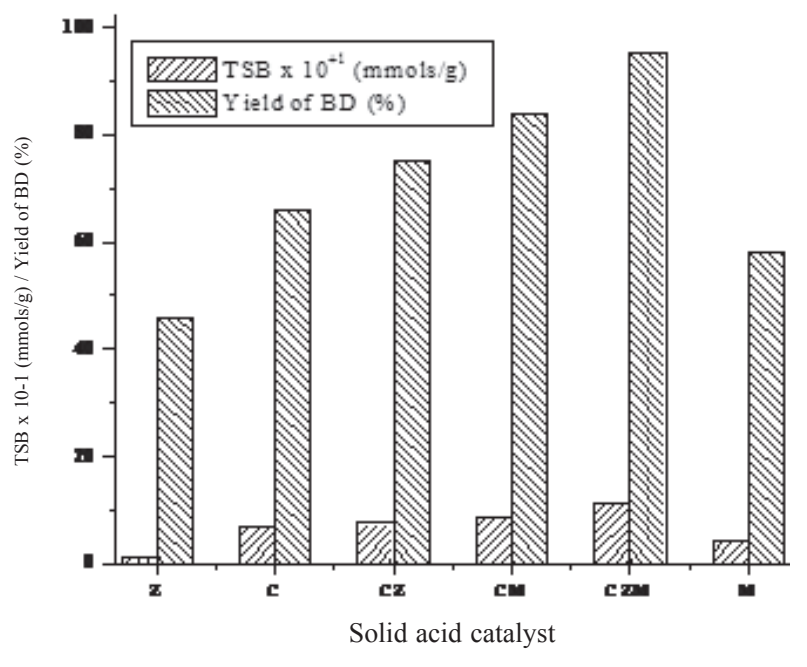

Fig. 4. Yield of BD as a function of TSB of solid base catalysts.

Effect of molar ratio of $\mathrm{MeOH}$ : $\mathrm{P}$-oil in esterification

The effect of molar ratio of MeOH: P-oil was studied over SC, $\mathrm{CZ}, \mathrm{SCZ}$ solid acid catalyst. The molar ratio was varied from MeOH: P-oil = 6:1 to 18:1 (Figure 5).

It was observed that the $\%$ of FFA (Acid value) of P-oil got reduced from 2.5 to 1.6 , when the molar ratio of $\mathrm{MeOH}$ : P-oil was increased from 6:1 to 18:1. However, further increase in the concentration of $\mathrm{MeOH}$ beyond the molar ratio of 12:1, did not result in any much decrease in the acid value of P-oil. However, a slight increase in the acid value was observed when the molar ratio of $\mathrm{MeOH}$ : P-oil was increased beyond 12:1. A similar trend has been observed by Y. Wang, et al [23].

\section{Effect of molar ratio of MeOH: P-oil in transesterification}

The effect molar ratio of $\mathrm{MeOH}$ : P-oil was studied over M, CM, CZM solid base catalysts and the results are presented in Figure 6. The molar ratio was varied from $\mathrm{MeOH}$ : P-oil = $6: 1$ to $18: 1$.

It was observed that, an increase in the molar ratio of $\mathrm{MeOH}$ : P-oil increases the yield (\%) of biodiesel. A maximum yield of biodiesel up to $95 \%$ was observed at a molar ratio of MeOH: P-oil $=12: 1$. Further, an increase in the molar ratio of $\mathrm{MeOH} \&$ oil beyond 12:1 did not result in an increase in the yield (\%) of biodiesel. Therefore, molar ratio of $\mathrm{MeOH}$ : P-oil $=12: 1$ was found to be an optimized molar ratio for the present study.

\section{Effect of reaction time in esterification}

The effect of reaction time in esterification reaction of P-oil was studied over SC, CZ and SCZ solid acid catalysts in the time range from 1-5 $\mathrm{h}$ and the results are given in Figure 7.

Over all the catalysts the acid value of P-oil decreased when the reaction time was increased from $1 \mathrm{~h}$ to $3 \mathrm{~h}$. However, the acid value did not decrease beyond $3 \mathrm{~h}$ of reaction time.

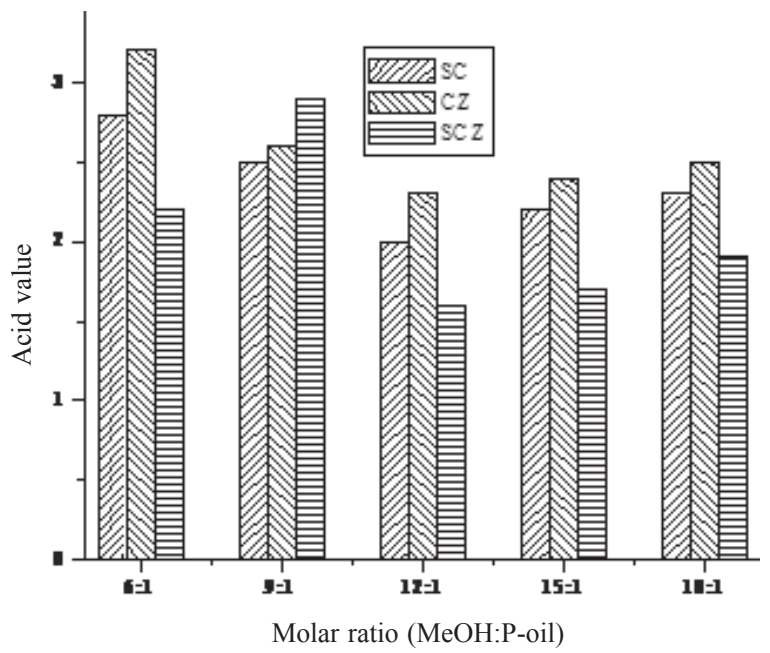

Fig. 5. Effect of MeOH: P-oil molar ratio on acid value. [Reaction conditions: amount of catalyst $=0.5 \mathrm{~g}$; reaction temperature $=$ refluxing temperature; reaction time $=3 \mathrm{~h}]$.

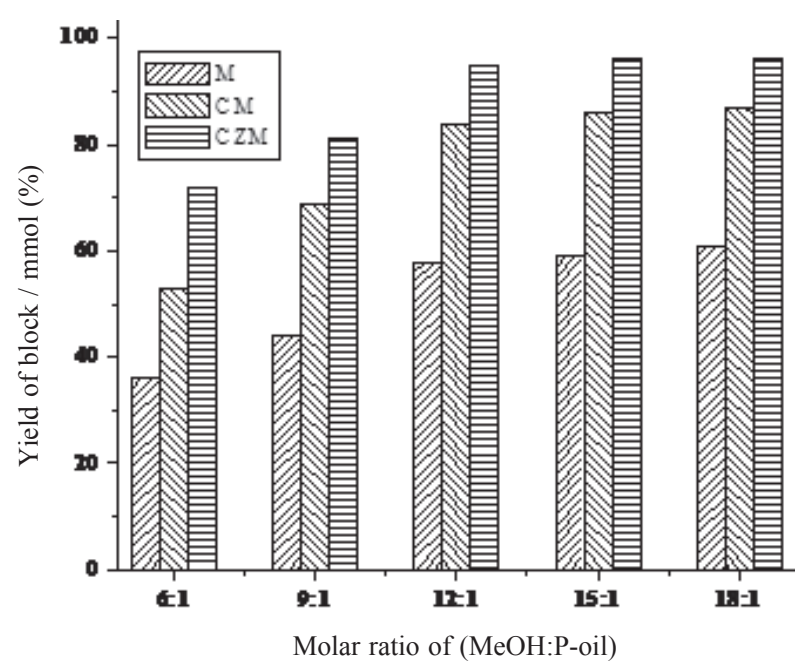

Fig. 6. Effect of molar ratio of $\mathrm{MeOH}$ : P-oil on transesterification. [Reaction conditions: amount of catalyst $=0.5 \mathrm{~g}$; reaction temperature $=$ refluxing temperature; reaction time $=3 \mathrm{~h}]$.

$1 \mathrm{~s}$ est., after $3 \mathrm{~h}$ of reaction period the acid value gets stabilized. Therefore, $3 \mathrm{~h}$ reaction time was found to be suitable to reduce the concentration of FFA in P-oil.

\section{Effect of reaction time in transesterification}

The yield (\%) of biodiesel with respect to reaction time was studied over solid base catalysts such as M, CM, CZM and the results are presented in the form a graph (Figure 8). It was observed that the yield of biodiesel increased in the first $3 \mathrm{~h}$ and then gets stabilized when the reaction time was increased beyond $3 \mathrm{~h}$. Therefore, a reaction time of $3 \mathrm{~h}$ was found to be suitable to obtain highest yield of biodiesel over a ceria based catalyst. 


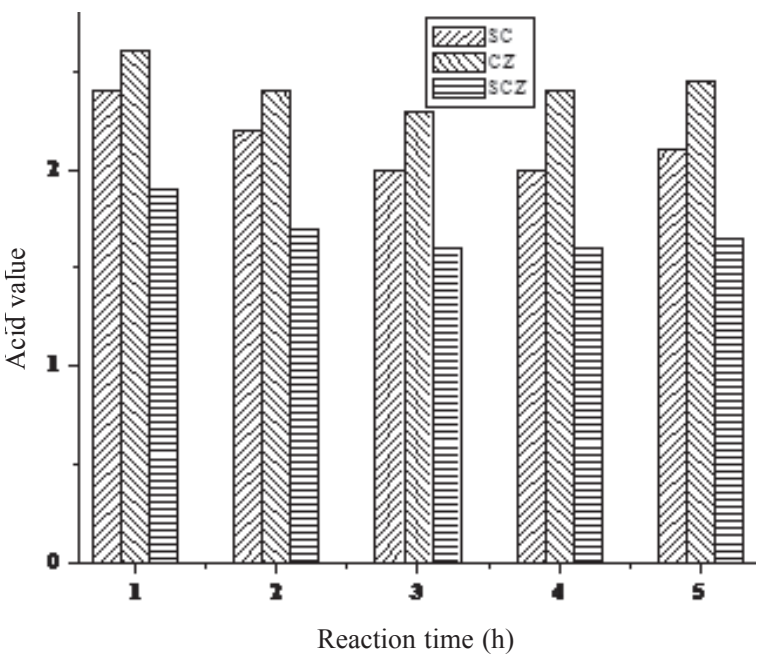

Fig. 7. Effect of reaction time on esterification. [Reaction conditions: molar ratio of MeOH: P-oil $=12: 1$; amount of catalyst $=0.5 \mathrm{~g}$; reaction temperature $=$ refluxing temperature $]$.

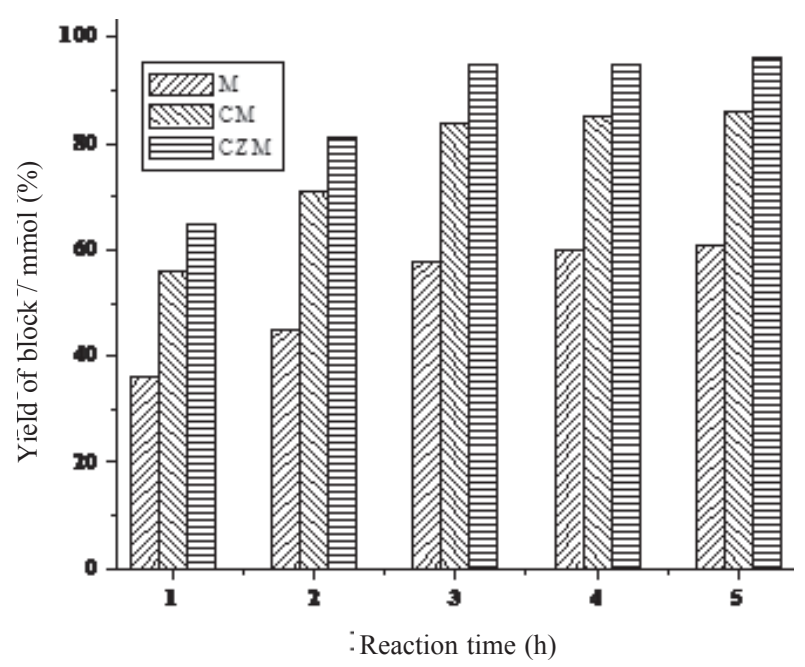

Fig. 8. Effect of reaction time on transesterification. [Reaction conditions: molar ratio of $\mathrm{MeOH}$ : P-oil $=12: 1$; amount of catalyst $=0.5 \mathrm{~g}$; reaction temperature $=$ refluxing temperature $]$.

\section{Analysis of biodiesel using $\mathbf{H}^{1}$ NMR}

The $\mathrm{H}^{1} \mathrm{NMR}$ spectrum of crude P-oil, esterified oil and biodiesel are given in Figure 9(a-c). The multiplet peak in the range 4.0 - $4.3 \mathrm{ppm}$ in the $\mathrm{H}^{1} \mathrm{NMR}$ spectra of esterified P-oil are due to the presence of glyceride protons. The unsaturated protons in esterified oil appear at 5.2-5.35 ppm.

Appearance of new peak at $3.66 \mathrm{ppm}$ due to $\mathrm{OCH}_{3}$ and disappearance of glyceride protons at 4.0-4.3 ppm in $\mathrm{H}^{1} \mathrm{NMR}$ spectrum of biodiesel (Figure 9c), favors the formation of biodiesel after the transesterification reaction of esterified of P-oil.

The presence of a multiplet between 5.2-5.35 ppm in the esterified and transesterified P-oil and the absence of the same in crude P-oil can be attributed to the protons of methyl ester.

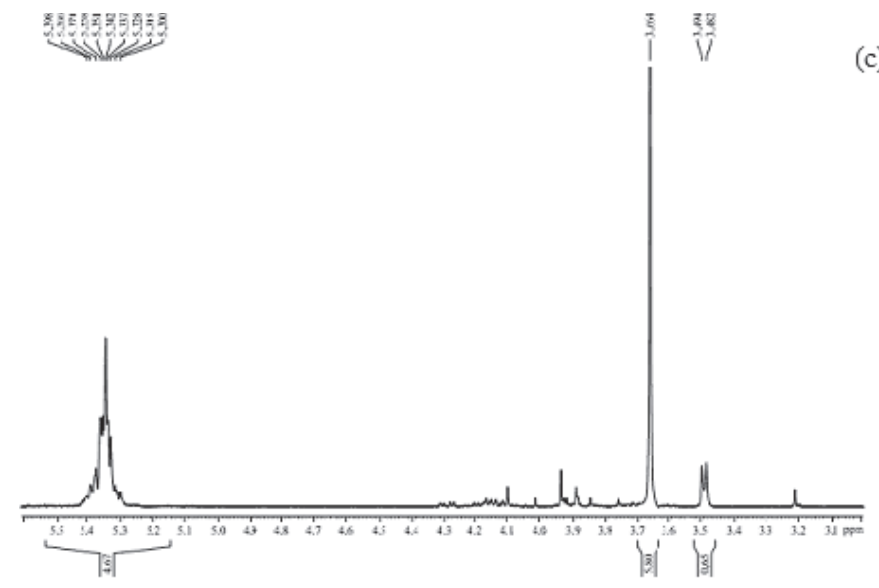

(c)

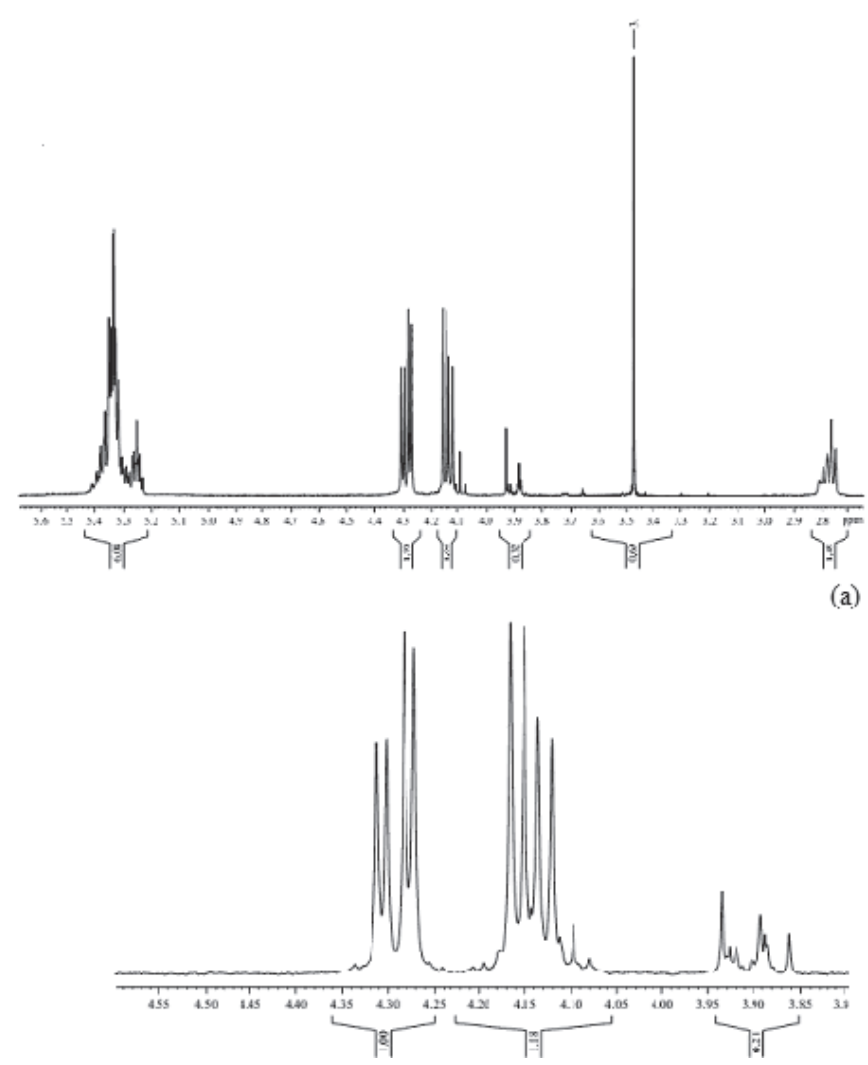

Fig. 9. $\mathrm{H}^{1} \mathrm{NMR}$ specta of (a) crude P-oil, (b) esterified P-oil and (c) biodiesel.

The purity of biodiesel formed after transesterification can also be explained using $\mathrm{H}^{1} \mathrm{NMR}$ by the following methods as reported in the literature [24].

Biodiesel is a mixture of mono, di, triglycerides associated with bound glycerol as an impurity. The presence of impurities in biodiesel sample must be lower than the limits specified by EN standards. The absence of major peaks in the range 3.9-4.5 ppm in $\mathrm{H}^{1} \mathrm{NMR}$ spectra of biodiesel after transesterification ruled out the presence of glycerol in prepared biodiesel sample [25]. 


\section{Reactivation and reusability of catalysts}

The catalysts (both solid acids and solid bases) recovered from the reaction mixture were washed with methanol and dried at $120{ }^{\circ} \mathrm{C}$ for $2 \mathrm{~h}$, calcined at $550{ }^{\circ} \mathrm{C}$ for $1 \mathrm{~h}$ in a muffle furnace before its use in the second reaction cycle. A similar procedure was followed for esterification and transesterification of P-oil for the reactivated catalysts up to 5 reaction cycles and the results are presented in the form of graphs in Figure 10 and 11 respectively.

\section{Reusability of solid acid catalysts}

In case of solid acid catalysts used for the present work, CZ \& SCZ were found to be more reusable, since not much decrease in the catalytic activity of these catalysts was observed even after 5 reaction cycles (Figure 10). However, a gradual decrease in the activity of SC was observed which can be attributed to the presence of 'strong' acid sites in SC which may decompose

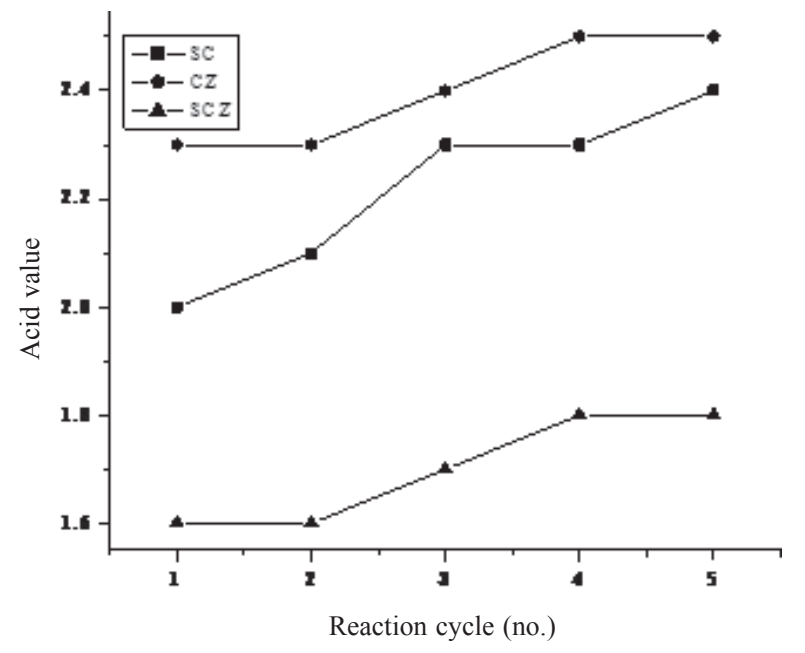

Fig. 10. Reusability of solid acid catalysts (SC, CZ, SCZ).

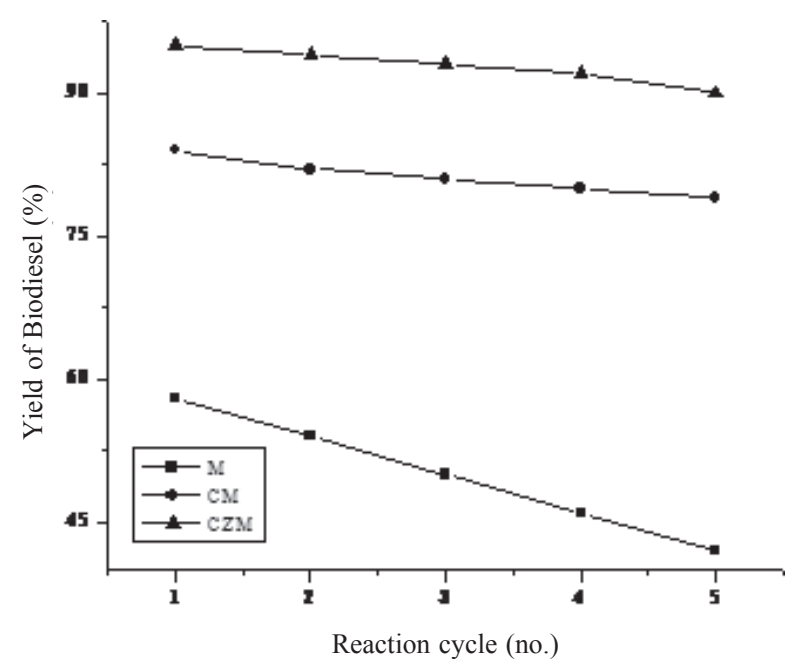

Fig. 11. Reusability of solid base catalysts (M, CM, CZM). the reactants or the product intermediates during the esterification reaction. This is also supported by the fact that the color of the catalyst (SC) as well as the reaction mixture could become grayish colored due to poisoning of acidic sites of SC during the reaction. This type of poisoning was not observed in case of CZ or SCZ catalysts since they consisted of 'weak' or 'moderate' or negligible number of 'strong' acid sites [21].

\section{Reusability of solid base catalysts}

Among the solid base catalysts used in the present work, M, CM, CZM were found to be efficient and reusable solid base catalysts for biodiesel synthesis (Figure 11).

When the reusability of pure $\mathrm{MgO}$ was compared with that of their mixed oxide forms such as CM or CZM, the latter were found to be more effective and reusable. This shows that the presence of ceria or ceria-zirconia improves the stability and activity of $\mathrm{MgO}$. Hence, mixed oxide of $\mathrm{MgO}$ with ceria or ceria-zirconia would be more reusable and efficient generally when compared to their individual counterparts.

In general, all the catalysts (either solid acids or solid bases) showed a decrease in their activity to a negligible extent with the number of reaction cycles which can be attributed to the possibility of sintering of the catalyst during reactivation process.

\section{Mechanism of biodiesel synthesis via transesterification over a base catalyst (B)}

The mechanism of base-catalyzed transesterification is described in Scheme 1. In the beginning methanol (an alcohol) adsorbs on the surface of the solid base catalyst producing a catalytically active alkoxide species $\left(\mathrm{CH}_{3} \mathrm{O}^{-}\right.$or $\left.\mathrm{RO}^{-}\right)$which is strongly basic and highly active (Pre-step). The next step

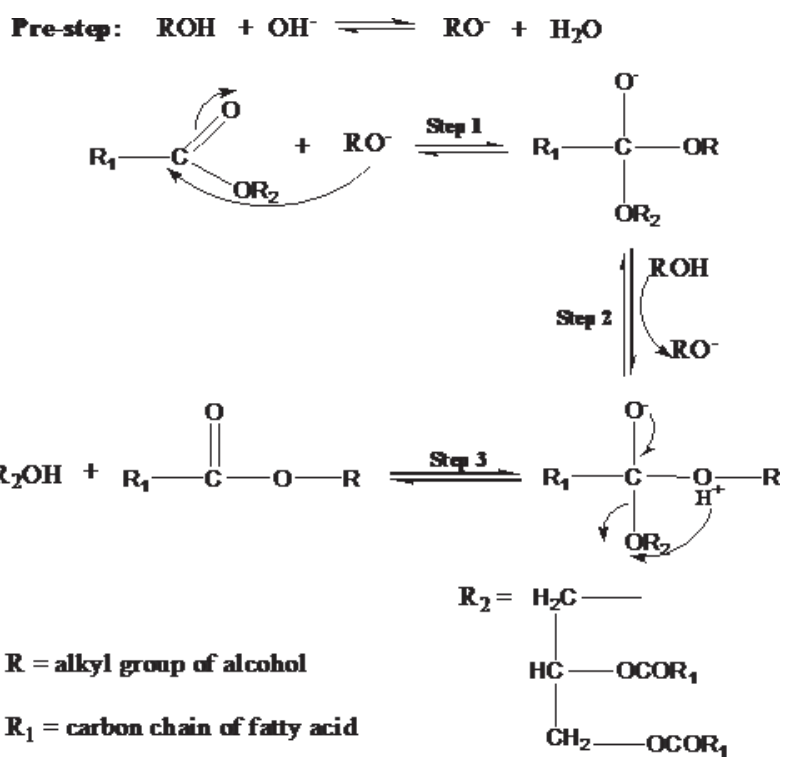

Scheme 1. Mechanism of biodiesel synthesis via transesterification over a base catalyst. 
involves the attack of the alkoxide ion $\left(\mathrm{RO}^{-}\right)$to the carbonyl carbon of the triglyceride molecule, which results in the formation of tetrahedral intermediate (Step 1). The reaction of this intermediate with an alcohol produces an alkoxide ion (Step 2). In the last step the rearrangement of the tetrahedral intermediate gives rise to an ester and a diglyceride (Step 3). Finally, the diglyceride ion reacts with the protonated base catalyst, which generates a diglyceride molecule and turns the base catalyst into the initial form. The resulting diglyceride reacts with another alcohol molecule, there by starting the next catalytic cycle. A similar mechanism for base catalysed transesterification has been reported by Bobade, etal [26] and Ulf Schuchardt, et al [27].

\section{Conclusion}

In the present study modified ceria catalysts were found to be more useful in the synthesis of biodiesel via transesterification of pongamia pinnata oil. Among solid acids sulfated ceria-zirconia and among solid bases ceria-zirconia-magnesia were found to be more efficient catalysts in esterification and transesterification reactions respectively. A correlation between the surface acidity or surface basicity and the catalytic activity of ceria catalysts was observed. Structure stabilizing effect of ceria or magnesia on zirconia was observed. The molar ratio of methanol: P-oil was found to influence both esterification and transesterification of the oil to a certain extent. A maximum yield of biodiesel (up to 95\%) could be obtained in a short reaction time of $3 \mathrm{~h}$. The ceria catalysts were found to be reactivable and reusable when used at least for 5 reaction cycles.

\section{Experimental}

\section{Materials}

The raw materials used for the synthesis of catalysts i.e., ceric ammonium nitrate, zirconyl nitrate, magnesium nitrate and sulphuric acid were obtained from LOBA Chemie India Pvt Limited. Pongamia pinnata oil was obtained from Channabasaveshwara oil Industries, Gubbi, Karnataka,

\section{Preparation of catalysts}

All the catalysts were prepared by impregnation method.

\section{(a) Preparation of ceria $\left(\mathrm{CeO}_{2}\right)$}

A known amount of ceric ammonium nitrate was mixed with a limited amount of deionised water. This mixture was made in to a paste. The resulting paste was dried in an air oven at 120 ${ }^{\circ} \mathrm{C}$ for $12 \mathrm{~h}$ and calcinated for $5 \mathrm{~h}$ at $550{ }^{\circ} \mathrm{C}$.

(b) Preparation of sulphated ceria $\left(\mathrm{SO}_{4}{ }^{2-} / \mathrm{CeO}_{2}\right)$

A known amount of uncalcined $\mathrm{CeO}_{2}$ was taken in a china dish to which $6 \mathrm{M} \mathrm{H}_{2} \mathrm{SO}_{4}$ was added and the resulting mixture was made in to a fine paste. The paste was dried at $120{ }^{\circ} \mathrm{C}$ for $12 \mathrm{~h}$ and calcined at $550{ }^{\circ} \mathrm{C}$ for $5 \mathrm{~h}$.

(c) Preparation of ceria-zirconia $\left(\mathrm{CeO}_{2}-\mathrm{ZrO}_{2}\right)$ mixed oxide Known amount of ceric ammonium nitrate and zirconyl nitrate were mixed with limited amount of deionized water. This mixture was made in to a paste. The resulting mixture was dried in an air oven at $120^{\circ} \mathrm{C}$ for $12 \mathrm{~h}$ and calcined for $5 \mathrm{~h}$ at 550 ${ }^{\circ} \mathrm{C}$.

(d) Preparation of sulphated ceria-zirconia $\left(\mathrm{SO}_{4}{ }^{2-} / \mathrm{CeO}_{2}{ }^{-}\right.$ $\mathrm{ZrO}_{2}$ )

A known amount of uncalcined $\mathrm{CeO}_{2}-\mathrm{ZrO}_{2}$ mixed oxide was taken with a limited amount of deionized water to which $6 M \mathrm{H}_{2} \mathrm{SO}_{4}$ was added and the resulting mixture was made in to a fine paste. The paste was dried at $120^{\circ} \mathrm{C}$ for $12 \mathrm{~h}$ and calcinated at $550{ }^{\circ} \mathrm{C}$ for $5 \mathrm{~h}$.

(e) Preparation of ceria-magnesia $\left(\mathrm{CeO}_{2}-\mathrm{MgO}\right)$ mixed oxide Known amount of uncalcined ceria and magnesium nitrate were mixed with a small quantity of deionised water. This mixture was made in to a paste. The resulting mixture was dried in an air oven at $120{ }^{\circ} \mathrm{C}$ for $12 \mathrm{~h}$ and calcined for $5 \mathrm{~h}$ at $550{ }^{\circ} \mathrm{C}$.

(f) Preparation of ceria-zirconia-magnesia $\left(\mathrm{CeO}_{2}-\mathrm{ZrO}_{2}-\mathrm{MgO}\right)$ mixed oxide

A known amount of uncalcined $\mathrm{CeO}_{2}-\mathrm{ZrO}_{2}$ and magnesium nitrate along with a small quantity of deionised water were taken in a china dish. This mixture was made in to a paste. The resulting mixture was dried in an air oven at $120^{\circ} \mathrm{C}$ for $12 \mathrm{~h}$ and calcinated for $5 \mathrm{~h}$ at $550{ }^{\circ} \mathrm{C}$.

(g) Preparation of magnesia $(\mathrm{MgO})$

Known amount of magnesium nitrate was mixed with a limited amount of deionised water and made in to a paste. The paste was dried in an air oven at $120^{\circ} \mathrm{C}$ for $12 \mathrm{~h}$ and calcined for 5 h at $550{ }^{\circ} \mathrm{C}$.

\section{Characterization of catalysts}

All the catalysts were characterized for their surface acidity and surface basicity by $\mathrm{NH}_{3}-\mathrm{TPD}$ and $\mathrm{CO}_{2}$-TPD methods. The crystallinity was analyzed by obtaining Powder X-ray diffraction (PXRD) patterns recorded by X-ray powder diffractometer (Philips X'pert) using $\mathrm{CuK} \alpha$ radiation $\left(\lambda=1.5418 \mathrm{~A}^{\circ}\right)$ over graphite crystal monochromator.

\section{Catalytic activity studies (in Biodiesel synthesis)}

Biodiesel from P-oil was synthesized in 2 steps.

Step-1: Esterification of P-oil over solid acid catalysts Since, crude P-oil consisted of high \% of FFA ( $\approx 4.8 \%)$ the $\%$ of FFA had to be reduced to $<2 \%$ by esterification of P-oil with methanol $(\mathrm{MeOH})$ using solid acid catalysts $(\mathrm{C}, \mathrm{Z}, \mathrm{CZ}$, SC, SCZ) (Scheme 2). 


\section{$\mathrm{R}-\mathrm{OCOH}+\mathrm{CH}_{3} \mathrm{OH} \stackrel{\text { Solit ach }}{\longrightarrow} \mathrm{CH}_{3} \mathrm{OCOR}+\mathrm{H}_{2} \mathrm{O}$}

Scheme 2. Esterification of P-oil with $\mathrm{MeOH}$ over solid acid catalysts to reduce the $\%$ of FFA.

Procedure: A known amount of P-oil was taken in a $250 \mathrm{ml} \mathrm{RB}$ flask fitted with a water cooled condenser. Known amount of a solid acid catalyst $(0.5 \mathrm{~g})$ and methanol were added to it.

The reaction mixture was refluxed for $3 \mathrm{~h}$ in a temperature range of $70-80{ }^{\circ} \mathrm{C}$. The $\%$ of FFA in P-oil, after the esterification reaction was determined by calculating its acid value by conducting acid-base titration as described elsewhere [15] .

Acid value is calculated by using the formula:

$$
\text { Acid value }=\left(X_{1}-X_{2}\right) / X_{1}
$$

where, $\mathrm{X}_{1}=$ volume of base required for P-oil before esterification.

$\mathrm{X}_{2}=$ volume of base required for P-oil after esterification.

Step-2: Transesterification of P-oil over solid base catalyst After reducing the \%FFA from P-oil, it was subjected to biodiesel synthesis via transesterification (Scheme 3).

Procedure: Transesterification reactions were carried out with known amounts of P-oil and methanol (MeOH) over $0.5 \mathrm{~g}$ of solid base catalysts (C, Z, M, CZ, CM, CZM).

The reactions were carried out in a $250 \mathrm{ml} \mathrm{RB}$ flask fitted with water cooled condenser. All the reactions were carried out in a reaction temperature ranging from $70-80{ }^{\circ} \mathrm{C}$ for $3 \mathrm{~h}$. After the completion of the reaction, the reaction mixture was centrifuged. After separating the catalyst, the reaction mixture was transferred to a separating funnel. The upper layer consisting of biodiesel was washed with hot distilled water for refinement. The traces of catalyst if any, was separated from the biodiesel by centrifuging. Thus obtained biodiesel was analyzed by GCMS (Hewlett Packard) fitted with a capillary column (HP-624, $30 \mathrm{~m} \times 25 \mu \mathrm{m} \times 0.25 \mu \mathrm{m}$ ) and $\mathrm{H}^{1} \mathrm{NMR}$ spectroscopy (Bruker NMR spectrometer, $400 \mathrm{MHz}$ ).

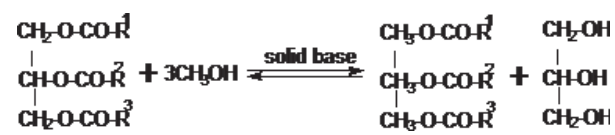

Scheme 3. Transesterification of esterified P-oil over a solid base catalyst to synthesize biodiesel.

\section{Acknowledgements}

We are grateful for the financial support given by DST, New Delhi. We Acknowledge SAIF, IISc Bangalore and St. Joseph College, Bangalore for $\mathrm{H}^{1} \mathrm{NMR}$ and PXRD analysis respectively. The authors are also thankful to IITM, Chennai for TPD analysis.

\section{References}

1. Canakci, M. Biores. Technol. 2007, 98, 183-190.

2. Merchetri, J. M.; Miguel, V. U.; Errazu, A. F. E. Renew and Sust. 2007, 11, 1300-1311.

3. Nie, K.; Xie, F.; Wang, F.; Tan; Lip, T. J. Mol. Catal. B: Enzyme 2006, 43, 142-147.

4. Zullaikah, S.; Lai, C. C.; Vali, S. R.; Ju, Y. H. Biores. Technol. 2005, 96, 1889-1896.

5. Lopez, D.; Goodwin Jr. J. G.; Bruce, D. A.; Latero, E. Appl. catal. A-Gen. 2005, 295, 97-105.

6. Caballero, J. M. R.; Gonzalez, Jr.; Robles, J. M.; Tost, R. M.; Lopez, A. J.; Torres, P. M. Appl. Catal. B-Environ. 2009, 91, 339-46.

7. Li E., Xu Z. P.; Rudolph V. Appl. Catal. B-Environ. 2008, 88, 42-9.

8. Lermontov, S. A.; Malkova, A. N.; Yurkova, L. L.; Baranchikov, Ye. A.; Ivanov, V. K. Nano Sys. Phy. Che. Mat. 2013, 4(5) 690695.

9. (a) Pengpaniche, S.; Meeyoo, V.; Ricksomboon, T.; Bunyakiat, K.; Appl. Catal. A. 2002, 234, 221. (b) Benjaram M. Reddy; Pavani M. Sreekanth; Pandian Lakshmanan; Ataullah Khan. J. Mol. Catal. A. 2006, 244, 1-7.

10. Sharma, Y. C.; Singh B. Fuel 2008, 87, 1740-1742.

11. Avinash Kumar Agarwal; Tanu Priya Bajaj. Int. J. Oil Gas \& Coal Technol. 2009, 2, 297-310.

12. Shamsundar, M.; Mohammed Shamsuddin, S. Z. Korean J. Chem. Eng. 2013, 30(12), 2186-2190.

13. Sanjib Kumar Karme; Anju Chadha. Bioresource Technol. 2005, 96, 1425-1429.

14. Hass; S. J. Am. Oil Chem. Soc. 1999, 73.

15. Thiruvengadravi, K.V.; Nandagopal, J.; Baskaralingam, P. Sathya Selva Bala, V.; Srivanesan, S. Fuel. 2012, 98, 1.

16. Sugunan, S.; Kumaree Seena, C. R. Indian J. Chem. 1999, 38A, 1123-112.

17. Putla Sudarsanam; Baithy Mallesham; Padigapati Reddy, S.; Benjaram Reddy; M. J. Chem. Sci. and Technol. 2013, 3, 161-168.

18. Hussein A. Khalaf. Khalaf Spinger Plus. 2013, 2, 619.

19. Sunaja Devi, K. R.; Jayashree, S. Reaction Kinet. Mech. Catal. 2013, 108, 183-192.

20. Yadav, G. D.; Nair, J. J. Micropor. Mesopor. Mater. 1999, 33, 1.

21. Benjarm Reddy, M.; Pavani Sreekanth, M.; Pandian Lakshmanan; Ataullah Khan. J. Mol. Catal. A, 2006, 244, 1.

22. Sandip Rathod; Madhukar Navgire; Balasaheb Arba; Machhindra Lande. S. Afr. J. Chem. 2012, 65, 196-201.

23. Wang, Y.; Pengzhan Liu S. O.; Zhang Z. Energy Conver. Management. 2007, 48, 184-188.

24. Knothe. J. Am. Oil Chem. Soc. 2001, 78, 10258.

25. Serdarevich, B.; Carroll, K. K. J. Lipid Res. 1996, 7, 277-284.

26. Bobade, S. N.; Khyade, V. B. Res. J. Chem. Eng. 2012, 2(8), 4350 .

27. Schuchardt, U.; Serchel, R.; Vargas, R. M. J. Braz. Chem. Soc. 1998, 9, 199-201. 